\title{
Editorial \\ Revisiting the state of the field: Some reflections on the 10th anniversary of Latino Studies
}

Latino Studies (2012) 10, 281-289. doi:10.1057/lst.2012.29

After serving 10 years as editor of Latino Studies, I am stepping down from this position. As I begin to write this, my last editorial, I can't help but think back to the historical context in which we were living in 2002-2003, when we founded the journal. The field of Latino Studies had only recently emerged in the early 1990s - an outgrowth of both the more established fields of Chicano/a Studies and Puerto Rican Studies, and of the growing diversity of the Latino/a population in the United States.

The society was still living the repercussions - both political and social - of the terrorist bombings of 2001. The voices in support of the "End Racial Profiling Act of 2001" (ERPA 2001), which had been heard loud and clear across the nation throughout the summer before 9/11 (Ofaolain, 2011), were suddenly and unambiguously muted by a growing chorus of support, grounded in fear and revenge, for the invasion of Afghanistan. The PATRIOT Act, signed into law later that year, and officially endorsing racial profiling particularly but not only against Arab Americans, was in full swing - and its implementation has since been intensified such that, today, it includes government-sanctioned surveillance of Muslim institutions and lives (Ginatta 2012; Sherman, 2012). Less than 2 years later, in the Spring of 2003, the invasion of Iraq served to reinforce the legal stifling of civil liberties.

At the same time, and despite the surge of militarization and controls along the US-Mexico border, the numbers of Latin American immigrants and of US born Latino/as continued to grow such that, by the summer of 2003, Latino/as officially were declared the largest minority in the United States. Latino/a communities emerged and/or became more visible including in new regions such as the Deep South - a development that has both affected Latino/as' settlement patterns and relations and had serious consequences, particularly for African Americans as well as for Whites and other groups in the South and across the country. Partially as a result, in the course of these 10 years Latino/as have increasingly become a key target of ever-growing racial prejudices and 
1 One of the results of the past decade's increasingly draconian antiimmigrant policies and practices is that by 2009 , Latino/as had become the largest minority in US federal prisons. More recently, drawing from a US Sentencing Commission report, the Daily Kos documented that, '[f]or the first time, Hispanics made up the majority of all federal felony offenders sentenced in the first nine months of fiscal year 2011 ... . [comprising] 50.3 percent of all people sentenced in that time period, blacks 19.7 percent and whites 26.4 percent' (seeta08, 2011). discrimination, today often supported by official anti-immigrant legislation, public policy initiatives, local ordinances and overt racial profiling practices in various states, from California to Arizona, Nevada and Colorado, from Iowa, Indiana and Illinois to Georgia, Mississippi and Alabama, from Pennsylvania, New Jersey and Massachusetts, to Rhode Island and the northernmost cities of New York state. In short, across the country today, a growing number of legislative acts, public policies and rampant social prejudices have ensured that Latino/as' lives are continuously threatened by family separations, detentions, incarcerations ${ }^{1}$ and deportations, creating a climate of terror and constant fear in our communities, often regardless of legal status.

Latino/as have responded with a firm determination, grounded in human dignity, to the onslaught of prejudice and discriminatory practices that continues to be in full evidence. Marches and protests organized and led by Latino/as have emphasized their efforts to rally the nation to improve the plight of the most recent newcomers and to withstand the determined assault on general democratic rights and ideals - whether through strikes and sit-downs involving Latino/as in the fields and urban centers of the country; the crosscountry Immigrant Workers Freedom Rides of 2003; the massive protests of 2006-2007 that saw millions of Latino/a citizens and residents nationwide take to the streets of towns and cities; the protests and demonstrations over the various anti-immigrant ordinances and legislation in Arizona, Georgia, Alabama, and elsewhere; the ongoing participation in the nationwide movement of the 99 per cent that began in New York City, in September of 2011. Moreover, the country has witnessed Latino/as' participation in all spheres of life and society of the United States, including the appointment of the Puerto Rican judge Sonia Sotomayor to the Supreme Court in 2009.

Aware that visibility is a precondition for the affirmation of citizenship and belonging, Latino/as' efforts in this direction have also been expressed by undocumented youth, whose struggle for the passage of the DREAM Act in recent years has led growing numbers of young Latino/as to come out of the shadows, supported by millions of other second and later generation Latino/a youth. Taking to the nation's highways, streets and pulpits, Latino/a youth today are publicly asserting their right to inclusion, to education, to health care, to jobs, thus making visible and publicly affirming their rightful presence as active participants in and productive contributors to US society. Through marches, demonstrations, cultural expression, films, music, the arts - they too have been increasingly demanding, above all, the society's recognition of their multiple ways of belonging.

In the course of these 10 years, we have also mourned several of our influential elders, including Frank Bonilla, Gloria Anzaldúa, Luis Leal, Raul Salinas, Rodolfo "Corky" González, to name only a few of the brilliant and committed Latino/a scholars, writers, artists and cultural workers, organic intellectuals and activists, who lived lives deeply committed to justice, to dignity and rights. Certainly, without them, the scholarship in our field would not be 
grounded as firmly as it is today in the high ideals, motivations, intellectual and scholar activist practices that this journal has upheld from its very beginning.

In our ongoing effort to bridge the gap between the lived experiences of the diverse Latina and Latino communities across the country, and the production of knowledge about them, the research and essays published in the first 10 volumes of Latino Studies - whether as scholarly articles, as reviews of recent books and documentaries on the Latino/a experience, or as essay contributions to the journal's Vivencias: Reports from the field, Reflexiones Pedagógicas, Páginas Recuperadas or El Foro sections - have documented and reflected on the important political and social events and cultural production of the period, analyzing and interpreting their implications for both US Latino/as and the country as a whole. With the continuous support of our journal's Editorial and International Advisory Boards and of hundreds of peer-reviewers around the country, our authors have discussed in theoretically rigorous and cutting-edge ways many of the historical and contemporary experiences and the resulting advances and changes made by Latino/as in the political, economic, environmental, social, cultural and artistic arenas of the United States. Their scholarship is a testament to the extent to which our field has grown, and further evidence that our scholars, researchers, students and administrators have a firm and growing presence in academia today. Nevertheless, the number of Latino/as in higher education, whether faculty, students or administrators, continue to be significantly hampered by the ongoing exclusion and racial prejudices rooted in over a century of discrimination, and that permeate the broader Latino/a community's experiences in the United States.

No doubt, my cursory attempt to trace a few of these changes in our field here invariably includes subjective criteria. Perhaps one way to measure "the distance traveled" in this brief and certainly incomplete reflection on our field's development over the past 10 years is to look back at the "Open Letter to University Presidents," published as an editorial in VOL I. I leave it to our journal's readers to determine the extent to which both the issues raised and the overall thrust of this "open letter" of 2003 remain pertinent and actual even today:

\section{An Open Letter to University Presidents: The Necessity for Latino Studies ${ }^{2}$}

Dear University President:

It is with great enthusiasm that I write in support of the establishment of a strong program in the growing field of Latino/a Studies at your University. There is no doubt that the establishment of this program will greatly enhance the institution's position in the national academy. After all, as I know you are aware, unlike in the past, a key component of the

2 First published in Latino Studies, 1(3): 361-365 (24 November 2003). 
mission of most universities today entails serving the national community as a whole by creating greater self-awareness and self-knowledge in the society. One aspect of this responsibility is the need to diversify the American imaginary to include the multiplicity of ethnic backgrounds, national origins, cultural roots, and religious traditions that are visibly represented in the population, and which have contributed to making this nation what it is. In other words, by incorporating the historical and contemporary experiences, diverse cultures, and contributions of Latino/as into the curriculum, the University contributes to the greater good, thus ensuring that the institution lives up to its highest ideals as well as to its societal responsibilities. In order to substantiate this point, allow me to discuss some of the pressing issues it raises not only for the University's Latino/a faculty and students but also and equally importantly, for the University community as a whole. Let me review the implications of some of these issues specifically as they pertain to a liberal arts education today.

As you are probably aware, the notion of Latino/as as an ethnic group, recognized as such by the federal government, emerged in 1977 under the name of "Hispanics," bringing together two US historical minorities (Chicano/as or Mexican Americans and Puerto Ricans) and immigrant populations, whether recent arrivals or otherwise, from all the Spanishspeaking countries of the hemisphere, as well as from Spain. The current generation of Latino/a college students are thus the first group of Latino/as to grow up defined as Latino/as by both themselves and US society. Previous generations were referred to as members of distinct communities (e.g. Chicano/as or Mexican-Americans; Puerto Ricans, Cubans, Dominicans, etc.).

This does not mean that members of this generation of Latino/as do not also identify themselves in terms of their parents' national identities and ties to Latin American countries. However, in order to understand fully the identity formation and concerns of this new generation, it is important to recognize that precisely because they have grown up in this country as Latino/as, their schooling, socialization experiences, and sense of belonging to the United States (in short their national identities and citizenship allegiances) have tied their immediate personal concerns and intellectual interests to the social, economic, political, and cultural conditions of the communities in which they have been brought up in this country.

The rise in ethnic group consciousness in the United States, however, has not been matched by any significant accompanying curriculum changes, 
either in high school textbooks or in college curricular offerings. Moreover, as evidenced by the recruitment efforts, actual student enrollments, and hiring practices, relative to the changing demographics in the United States, most institutions of higher learning are still not fully cognizant of the implications of the changing composition of the US-born populations.

The official count of Latino/as is now over 38 million people, ${ }^{3}$ making them the largest minority group in the country. Yet according to the March 1999 Current Population Survey report of the US Bureau of the Census, for example, only $11 \%$ of all Latino/as are in fact college graduates today. ${ }^{4}$ Still, the fact that for the first time in US history African Americans are no longer the largest minority population in the United States does have serious consequences both for the future of this society and, hence, for all educators - regardless of their fields of specialization.

Clearly, increased numbers do not necessarily signify increased empowerment. Nevertheless, a number of issues are raised by perpetuating the traditional black-white framework, which is still used to understand the increasingly complex relations and tensions in our society. For example, although the media portrayal of the 1992 Los Angeles riots focused squarely on the history of black-white tensions, a significant number of the protestors were Latinos. A greater understanding of the implications of this phenomenon would undoubtedly contribute to improving our nation's public policy initiatives. Similarly, it is increasingly apparent that the contemporary issues that the growing Latino/a community raise for the nation around, for example, immigration, poverty, language choice and usage, unemployment, racial profiling, or the position of foreigners in our society, require not only additional significant research but also, minimally, a new paradigm for addressing the virulent consequences of racism in our nation. It is essential that we develop a deeper understanding of the ongoing relevance of the historical black/white framework even as we strive to develop new theoretical constructs that can also account for inter-racial dynamics grounded in the multiple social experiences of Latino/as. Equally important is the need for more research on the implications of Latino/as' varied political status (whether as citizens, residents, immigrants or refugees) as well as of the myriad socio-economic and cultural commonalities and differences among them.

The growing tensions between Latino/as and African Americans or EuroAmericans throughout the 1990s, and into the 21st century - whether in New York, California, Chicago, Houston, North Carolina, or Miami require our urgent attention as scholars and researchers. For they are at least partial evidence of the increasing presence and frustration of
3 By 2010, this number had grown to 50.7 million (or 16 per cent of the US population) (Motel, 2012).

4 In 2010, 13.1 per cent of the Latino/a population had a college degree (Motel, 2012). 
5 The new

Supplemental

Census Measure

released in 2011

confirmed that this

trend continues

today. In 2010,

Hispanics had the

highest poverty

rates, with 28.2 per

cent of the

population living

in poverty (Lopez

and Cohn, 2011).

6 In 2010, 62.9 per cent of Latino/as were born in the United States.

Moreover, data
Latino/as concerning the persistent political invisibility and dismal socioeconomic conditions in which significant numbers of Latino/as struggle to live their lives. In fact, recent Census reports document that Latino/as have now surpassed African Americans to become the poorest group in this society. ${ }^{5}$ This cannot be attributed to the larger number of recent immigrants from Latin America.

According to the National Council of La Raza, Puerto Ricans - who have formally been US citizens since 1917 - are the poorest group within the Latino/a population. Moreover, Census data released on March 8, 2000, show that while $1 / 4$ of the nation's 31 million Latino/as live in poverty, $27 \%$ of them are Puerto Rican families, as compared with $24 \%$ of Mexican families or $11 \%$ of Cuban households. What can this tell us about the need to acknowledge the unusual political status and anomalous place of Puerto Rico in the study and understanding of US history, politics and society? Similarly, there are data to suggest that third-generation Mexican-Americans have a significantly higher dropout rate and lower self-esteem than their US-born parents. Again, from the perspective of understanding the trends in US education, for example, what are we to make of the fact that arriving immigrants fare better in this country's schools than the children of US-born and raised third-generation citizens of Mexican descent?

In other words, regardless of one's ethnicity or field of specialization, knowledge and further research of these conditions as well as of Latino/as' social and cultural specificities is as essential in addressing societal problems such as school dropouts, AIDS, or teenage pregnancy, as it is in understanding the importance of Latino/as today, to political developments across the United States. Along with their significant economic contributions, they are increasingly present and involved in the shaping of regional political outcomes throughout the country.

Will this trend be reversed? Given the available evidence to date, it seems highly unlikely. In spite of the different national origins encompassed by the federally created term "Hispanic," according to a 1997 population report, $55.9 \%$ of the then 29.6 million Latino/as were mainland born and an additional $8 \%$ were US citizens born in Puerto Rico. The actual figures are much higher given that these percentages do not include naturalized citizens. ${ }^{6}$ Still, even then, the fact remained that the majority of Latino/as in the United States are not necessarily immigrants: rather, they are unequivocally citizens of the United States. Insofar as there are Latino/as who are descendants of Spanish-speaking populations who were on what today is US territory since before the arrival of the pilgrims, it is not 
surprising that Latino/as are increasingly organizing to demand the civil rights and political recognition afforded to all US citizens. Moreover, given the ongoing immigration from every country in the Americas, the establishment of dual nationality laws by a number of countries in the hemisphere, and the ultimate aim of the North American Free Trade Agreement implemented in 1994 - that is, the development of a common market throughout the hemisphere - the visibility and presence of Latino/ as in US society and politics will certainly increase.

The implications of these trends for Liberal Arts education both include and go beyond the issue of whether or not the University's Latino/a students recognize their community's experience in the curriculum. They also direct our attention to the pressing need to ensure that we incorporate this experience as part of all students' understanding of the society into which they will enter at the end of their University education. Furthermore, it makes it even more self-evident as to why a major institution such as yours, should commit itself to ensuring that a greater number of Latino/a Studies faculty are present in all disciplines across the curriculum. In making this commitment, the University community as a whole will be in a better position to understand and evaluate the consequences of the demographic phenomena I refer to above.

What we are discussing, then, is actually the means of enriching both the University curricula and the national community in ways that will enable all of us to deal more appropriately and effectively with the overall socio-ethnic and political changes underway. Given these objectives, it makes perfect sense to implement this program together with a responsible increase in the numbers of Latino/a faculty, students and courses, and, in so doing, to support fully their efforts to develop this growing new academic field at your institution. I hope you will agree that at this point the establishment of Latino/a Studies as a legitimate field of inquiry will have a significantly positive impact not only on the education of Latino/as around the country but also of all students attending the University.

I look forward to following the progress of these discussions and to the successful implementation of this very critical program, which I believe will contribute significantly toward enhancing the standing of your University in the academy and the nation. from the US

Census determined that an additional 10.9 per cent became citizens through naturalization (Motel, 2012), bringing the total number of Latino/ as who are US citizens, whether by birth or naturalization, to 78.8 per cent.

Sincerely,

Suzanne Oboler 
Certainly, although there have been significant advances, there is still much to be done in the name of justice, equity and rights of Latino/as, particularly in higher education. At the same time, I think it is important to acknowledge that despite the difficult and fraught road we still must travel whether as scholars, students or administrators, our field does have more visibility and is continuing to grow. And, at least partially as a result, Latino Studies is now a nationally recognized journal in our profession.

The development of Latino Studies over the past 10 years is clearly a tangible testament to the excellence and commitment of Latino Studies scholars across the country. I am deeply honored to have had the opportunity to contribute to the development of our field as founding editor of Latino Studies. I am proud to have been associated with a journal that subscribes to the ideal of promoting excellence in scholarship, while at the same time offering the mentoring that we believed was necessary for a journal that sees itself as both benefitting from and contributing to the development of a field. In this respect, I am very grateful to our authors and reviewers for their commitment to and support of Latino Studies. Above all, I want to express my deep gratitude to the journal's Associate Editors, Marisa Alicea, Raymond Rocco and Silvio Torres Saillant, and to the journal's Managing Editors over the years, especially Karen Benita Reyes; without their unwavering dedication and commitment, Latino Studies would not have achieved its current status in our field. I also thank Frances Aparicio, who secured our journal's initial contract with Palgrave Macmillan, for her vision and leadership, and all the former and current members of the International Advisory Board of Latino Studies for their valuable service to the journal and the field. Last, but by no means least, I thank David Bull, the journal's Publishing Director at Palgrave Macmillan UK, for his guidance, which undoubtedly contributed to the growth and success of Latino Studies, and John Jay College of Criminal Justice-CUNY and the University of Illinois, Chicago for their generous support of the journal and my editorial responsibilities during the past decade.

Finally, I wish Lourdes Torres all the best as she takes on the editorship of Latino Studies. I am certain that under her leadership, the reputation of this journal will continue to grow and to accurately represent the high-quality research and dedication of Latino/a scholars, professors, graduate students, administrators and activists throughout the United States.

Saludos!

\section{References}

Ginatta, A. 2012. US: White House is "Puzzling" on Racial Profiling. 1 May, http://www .hrw.org/news/2012/05/01/us-white-house-puzzling-racial-profiling, accessed 4 June 2012. 
Lopez, M.H. and D. Cohn. 2011. Hispanic Poverty Rate Highest in New Supplemental Census Measure. Pew Hispanic Center, 11 November, http://www.pewhispanic.org/ 2011/11/08/hispanic-poverty-rate-highest-in-new-supplemental-census-measure/, accessed 3 June 2012.

Motel, S. 2012. Statistical Portrait of Hispanics in the United States, 2010. Pew Hispanic Center, 12 February, http://www.pewhispanic.org/2012/02/21/statistical-portrait-ofhispanics-in-the-united-states-2010/, accessed 3 June 2012.

Ofaolain, S. 2011. The Policy Impact Ten Years since 9/11: End Racial Profiling Act (ERPA). Rights Working Group, 31 August, http://www.rightsworkinggroup.org/ content/policy-impact-ten-years-911-end-racial-profiling-act-erpa, accessed 4 June 2012.

Pew Research Center. 2009. Between Two Worlds: How Young Latinos Come of Age in America. Pew Hispanic Foundation Report, http://www.pewhispanic.org/2009/12/11/ vi-education-the-gap-between-expectations-and-achievement/, accessed 4 June 2012.

Seeta08. 2011. Latinos New Majority Sentenced to Federal Prison. 7 September, http://www .dailykos.com/story/2011/09/07/1014252/-Latinos-New-Majority-Sentenced-to-FederalPrison, accessed 4 June 2012.

Sherman, T. 2012. NYPD Muslim Surveillance in NJ "Permissible" According to Attorney General Report. 26 May, http://www.huffingtonpost.com/2012/05/26/nypd-muslimsurveillance-nj-permissible_n_1547231.html, accessed 4 June 2012.

Suzanne Oboler Founding Editor

John Jay College of Criminal Justice, The City University of New York, NY. E-mail: soboler@jjay.cuny.edu 